New Zealand journal of industrial relations, 1984, 69, 69-80

\title{
ARTICLES
}

\section{Managerial unionism and the law in New Zealand.}

\author{
Keith D Binnie* and David F Smith+
}

This paper examines the issue of trade unionism amongst the fastest growing occupational group in New Zealand, which is also the least unionised, managers and administrators. Despite facing similar threats to employment security and changes to working conditions as other wage and salary earners, most managers and administrators do not have - the benefits of a protective organisation to bargain on their behalf. The paper examines - forms of collective representation for managers, but particularly incorporation and registration as a trade union. Problems associated with attempts to register managerial unions are discussed, and the particular case of APEX is examined. The paper concludes with some suggestions for changes to the law to ease the plight of those managers who wish to unionise, and summarises the current avenues available for collective representation.

\section{Introduction}

Managers and administrators are the fastest growing occupational group in New Zealand; they are also the least unionised. Between 1956 and 1981, the number of managers and administrators increased by 140 percent compared with an increase of only 57 percent for the workforce as a whole. By 1981, the latest year for which figures are available, managers and administrators accounted for 1 in every 7 white-collar workers, and 1 in 14 of all wage and salary earners. Yet despite this, only about 14 percent of this occupational group is unionised, far lower than any other group in the workforce. Unionisation, even amongst professionals, stands at about 5 times this level. So what accounts for the low level of unionisation amongst managers and administrators in New Zealand? How does this group differ from other workers? Are they reluctant to join trade unions, or do opportunities for unionisation simply not exist for them in the same way they do for other workers? What difficulties face managers who wish to unionise, and what avenues for collective representation are open to them? In seeking to protect their employment interests, to whom can managers turn?

The question of managerial unionism is one which gives rise to considerable debate amongst managers themselves. Many managers believe themselves to be different from other workers, and there are undoubtedly many good reasons for this. Historically, especially in small organisations, managers had daily contact with owners and frequently came from similar backgrounds. They often saw their interests as being more closely aligned with employers than with the rest of the workforce. Furthermore, many managers

* Keith Binnie is legal officer for the New Zealand Association of Waterfront Employers.

+ David Smith is a senior lecturer in the Department of Business Administration, Victoria University of Wellington.

The financial assistance of the Social Sciences Research Fund, the University Grants Committee, the BP Industrial Research Award and the Victoria University Internal Research Committee is acknowledged. Helpful comments were received from two anonymous referees. 
have been conditioned in an individualist philosophy which makes them tend to spurn collective action. They believe that they are best equipped to look after themselves, and that their authority and status may be compromised if they band together with others. Some see unions as "unprofessional", but just what is meant by this is frequently not very clearly defined. In any case, it is difficult to give much credence to this claim since so many professionals are unionised. Others are "discouraged" by their own bosses from joining a union by a variety of means, some subtle some less so.

Most managers are employees, but in one sense they are different from other workers, and it is this. The function of management is to direct and control the work of others. This places them apart from other workers whose task it is to carry out instructions. Because of their function, managers may also differ in status and salary from other workers, and this also places them apart. But it is in the legal sense that managers are most clearly the same as other employees. Legislation in the employment field makes no distinction between employees according to their function. In the last analysis, it is the contract of employment which offers protection to employees, managers and workers alike, and in this respect many managers may find themselves in a weak position.

There is a fundamental imbalance in the employment relationship between the individual employee and his or her employer. Employees who are not members of a protective organisation have only themselves to rely on when it comes to employment-related negotiations. The reference point for the employment relationship is the contract of employment entered into at the commencement of the job. The individual manager or administrator is totally reliant on this contract which, almost certainly, will have been entered into at a time when future developments in the position or changes in the economic climate which make the position less secure could not have been anticipated. Managers have only their own bargaining power and their contract to draw on should they wish to obtain any changes or protection in their employment status.

Traditionally, managers have not had to worry about job security, and as a result have seen little need to join or form unions. But adverse economic times, or a change in the circumstances of the employer, such as that brought about by a company restructuring, may result in the manager being treated no differently from other employees, and in many cases less favourably. The recent well-publicised case of staff layoffs at International Computers in New Zealand brings home this point forcefully. Amongst the 23 staff made redundant without warning, were 3 regional general managers. Redundancy amongst managers and administrators is no longer uncommon. Without the advantage of a collectivity to provide a means of constructively resolving employment issues through jointly agreed procedures and negotiating machinery, managers may be left very much to fend for themselves. Faced with the prospect of these kinds of difficulties, managers may decide that collective representation is desirable, and consider unionisation, or some other form of collectivisation. Should they do so, what kinds of representation are possible and what difficulties must be overcome in attaining them? It is to a consideration of these issues that we now turn.

\section{Forms of collective representation for managers}

Workers seeking to protect their working conditions through collectives, generally have several choices regarding the type of organisation they can form to fulfil this objective. These range from informal groupings to incorporated societies and possibly registered industrial unions. Although some informal groupings, such as staff associations, do operate successfully in dealing with employers, generally they lack industrial strength. They may also be dominated by the employer and be more indicative of those interests than the interests of the people they are supposed to represent. Furthermore, they are often dependent upon the goodwill of the employer for their continued existence. For these reasons, the focus here will be upon the two other routes to collective representation, 
incorporation and registration. In examining these alternatives, particular attention will be given to the shortcomings of incorporation, the legal and procedural requirements for registration as a union, and the difficulties societies face in attempting to unionise. The case law relating to registration under the Industrial Relations Act, particularly as it impinges upon managerial unionism, will also be examined.

\section{Incorporation}

The Incorporated Societies Act 1908 makes provision for the incorporation of societies not established for pecuniary gain and sets out minimum procedural requirements that must be complied with before such societies may be incorporated. These deal mainly with what must appear in the rules and what activities the society may and may not engage in. However, the most significant aspects of incorporation for those wishing to form collectives are the implications that flow from it. Incorporation creates an important legal distinction between incorporated and unincorporated societies in bringing with it a separate legal identity for the society itself. Without incorporation, the society is simply a collection of individuals, whereas an incorporated society is a "legal person" itself, with its own rights, obligations and identity. The practical implications of this are that an individual, unsupported by a formal legal organisational structure, may often not be perceived as speaking with as much authority as one who speaks as the elected official of an incorporated society. Incorporation also gives the society perpetual succession; that is, its continued existence is not legally dependent on any one member having to operate it; though of course in practice it might be.

Clearly there are tactical industrial relations implications associated with incorporation in that there will inevitably be some psychological benefits from the increased formality and internal cohesion when dealing with employers on a collective basis. More importantly, however, a society may call on legal support for its negotiations through its recourse to Part X of the Industrial Relations Act. Though this provision applies to all societies of workers, whether incorporated or not, incorporation generally makes it easier for the society to operate (primarily because it requires a detailed set of rules and consequently a more formalised operating procedure) and is thus better able to take advantage of this provision. Part $\mathrm{X}$ of the Act provides for compulsory conciliation in the event of a dispute, which though not equivalent to recognition in the broad sense, nevertheless forces an employer to talk with a group of workers who have a grievance. Should a dispute arise, either party may give notice to the Registrar of the Arbitration Court of the terms of the dispute, who must in turn refer the matter to a conciliator. If a voluntary agreement is arrived at, it can then be filed with the Registrar, and binds the parties to it.

These advantages associated with incorporation are of considerable significance in the industrial setting, but there are some serious inequities between the bargaining status of incorporated societies and industrial unions that render the further step of registration as a union an essential course of action for many societies. Briefly these are as follows:

(1) There is no provision in Part $\mathrm{X}$ of the Industrial Relations Act whereby the parties to a dispute are entitled to compulsory arbitration on failure to reach a voluntary settlement. Thus, if the parties cannot formulate an agreement, even with the aid of a conciliator, the dispute must lie unresolved.

(2) Section 143 provides that the provisions in the Act relating to penalties for unjustified industrial actions, whether strikes or lockouts, shall apply to societies of workers and their employers in the same way as if the society were an industrial union and the voluntary agreement were an award.

(3) Whereas an award can continue in force for up to 3 years after its expiry date, an 
agreement (other than a collective agreement under the Act) between a society and an employer must lapse on its expiry date, and if there is no further agreement to supercede it, the terms of employment for workers will be whatever the employer decides.

(4) Prior to March 1984, unqualified preference clauses could be included in awards negotiated by industrial unions but not in agreements negotiated by incorporated societies. However, following the Industrial Relations Amendment Act 1983, this distinction between the two forms of organisation has been removed, it having been enacted that unqualified preference clauses could not be included in awards or collective agreements.

One may conclude, then, that from an employee's point of view, some of the potentially worst effects of the industrial law, such as the repercussions of strikes, but not the greatest benefits, such as compulsory arbitration (and formerly employment preference) apply to societies of workers. Incorporation as a society is often the first step taken by managers and other groups along the road to full trade union organisation. Some never progress beyond this point either because they see themselves as professional associations, avoiding any connection with the term "union", or because of the difficulties of union registration, which will be considered in more detail below.

The problems and shortcomings of operating as a collective without registration mean that sooner or later, societies of managers may attempt to improve their bargaining position when negotiating wages and conditions of employment by obtaining registration as an industrial union. With this in mind, we turn to a discussion of the procedures for registration.
registration.

\section{Registration}

The procedures for registration as an industrial union are set out in section 163 of the Industrial Relations Act 1973. The principal requirements are that the society must have more than a certain minimum level of membership and be lawfully associated for the purpose of protecting the interests of workers (or employers) engaged in any specified industry. The formalities of registration may be found in sections 163-165 of the Industrial Relations Act and do not require expansion here except to explain the implications of the Registrar of Industrial Unions' decision once he has received an application for
registration.

Should the Registrar be satisfied that the society is qualified to register under the Act, and that the provisions of the Act have been complied with, he will register the union; such registration rendering the union subject to the jurisdiction given to conciliation councils and the Arbitration Court, and subject to all the provisions of the Industrial Relations Act. If the Registrar refuses to register the society as a union, the society can appeal to the Arbitration Court, the onus of proof lying with the society to show that it should be registered as a "new" union.

The chief benefits of registration can be listed briefly as follows:

(1) In most cases, the union can compel an employer to settle a dispute through the conciliation and arbitration procedures in the Act. However, section 88 of the Act allows the Court to refuse to make an award. In recent cases, the Court has refused to grant an award where it felt that both the need and desire for an award were not shown. In the case of management employees, the requirements of section 88 could prove difficult in their attempts to secure an award, where there might be substantial opposition from employers. But in general, whether the dispute concerns the interpretation, application or operation of a current award, or the negotiation of a new award, if the two parties cannot agree upon a settlement, there are procedures in the Act which either party can invoke to have the matter finally dealt with. 
(2) The union is protected from the "poaching" of its membership by other unions by virtue of it being granted exclusive coverage over particular occupations and industries.

(3) For many unions, an advantage is that they are able to negotiate an award covering all employers in an industry.

The main disadvantage of registration concerns restrictions on the right to strike. However, as already mentioned, these restrictions apply equally to incorporated societies. Such benefits as those outlined above may prove attractive to groups of managers, just as they have to other groups. But before these potential benefits may be realised, the Registrar must make a decision in favour of the registration of the new union. Unfortunately, for groups of managers and administrators seeking registration, historically the odds are very much against them.

A decision in favour of registration is vital to union recognition. Such a decision means that all employers in the industry from which the union draws its membership must deal with that union as the negotiating collective. The advantages outlined above are automatically conferred upon the union on registration, because the employer is compelled to enter the conciliation and arbitration process once the status of "union" has been accorded to a group of workers. This statutory form of recognition differentiates the New Zealand system of industrial relations from many others, such as, for example, that of the United Kingdom (although for a time this was statutory), where recognition is an issue between the union and employer, and not, as in New Zealand, between the union and the Registrar.

Employer attitudes to the recognition of unions can have a significant effect on union growth. If employers are willing to recognise and deal with a union, workers are generally more willing to join the union than if they are not. Negative attitudes of employers to trade union recognition is one reason why managerial unionism has not progressed in some countries as fast as it otherwise might have. In New Zealand, where recognition is, in a sense, statutory, one might have expected to find that employer attitudes to recognition were largely irrelevant resulting in a postive impact on union growth amongst managers. This might have been the case had registration been straight forward. However, union registration is by no means a formality, and the case law surrounding attempts to establish managerial unionism in New Zealand is heavily weighted against the establishment of new unions.

According to section 168(2) of the Industrial Relations Act, the Registrar can refuse to register any society as a union if in his opinion the members of that society could conveniently belong to an already existing union. This section of the Act is designed to prevent the undue multiplicity of unions and gives the Registrar a very wide discretion to ensure that this is avoided.

There are other criteria which, if unsatisfied, will require the Registrar to refuse registration. These include insufficient precision in the wording of the membership clause and more generally, inadequacies or omissions in the rules of the union. The society must also be engaged in a "specified industry or related industries" which essentially means that it must cover workers in a specific "calling" or "occupation" or in a specific industrial sector such as agriculture, food manufacture and so on. However, it is upon the grounds of non-compliance with section $168(2)$ that most objections are encountered in attempts to register new unions and it is to the interpretation of this clause that we will now turn, and to the related matter concerning the very strict treatment given to the membership clause.

\section{The law in practice}

An early case in point concerns an application for registration by the Shipmasters' Association of New Zealand as an industrial union which was turned down by the Registrar. In his opinion, members of the Association could conveniently have belonged 
to the New Zealand Mercantile Marine Officers' Association IUOW. This opinion was formed in spite of the Unions' rules which excluded the Masters from having any real voice in the business of the union. (The rules stated that no more than 2 masters could be included on the management committee of the Union and that no business was to be transacted unless two thirds of those present were not masters).

The Arbritration Court upheld the appeal by the Association (Shipmasters'Association of New.Zealand v. Registrar, 1903) and reversed the Registrar's decision on the grounds that firstly, with rules such as these, the Union was not one to which members of the Association could conveniently belong; and secondly, that there was a diversity of interest beween the shipmasters and their officers such that the authority of the former would have been threatened if they had been required to join a union in which they had no effective say in the day-to-day affairs.

By the same token, the Registrar refused to register the Canterbury Chain Store Grocery Managers' Guild as a union on the grounds that no diversity of interest existed to justify separate unions being registered for both managers and their assistants, and that both could conveniently belong to the relevant Grocers' Assistants Union. Again this decision was overturned in the Arbitration Court (Canterbury Chain Store Grocery Managers v. Registrar, 1934) where it was stated that the general rule of the Court had been to separate workers who were genuinely in control of other workers from those they control. Thus it was proper to recognise managers of grocery stores as being on a different footing from their assistants and to have due regard to the fact that the delegated powers of control and other incidents of the duties and responsibilities of managers gave rise to a genuine diversity of interest between them and their assistants. The separation of managers from other workers in the eyes of the law relating to union registration seemed firmly established.

The Arbitration Court was emphatic in both these decisions that the relevant diversity of interest was sufficient to warrant the registration of a new union. The Registrar had clearly failed to take this into account, but rather, had approached his decision from the point of view of convenience to the existing union and not convenience to the members of the Guild or Association. His decision stated in effect that the nature of and relationship between the occupations of the various protagonists was irrelevant so long as the applicants worked in the same shop or on the same ship as their "opponents". It was thus more convenient for them to join the union that was already operating in the workplace.

When the Northern Totalisator and Allied Employees' Association applied for registration, it met with the same negative response as in the two cases just cited. The Registrar found that members of this association were eligible to join one of seven separate district clerical workers' unions or the New Zealand Engineers' etc. IUOW or the New Zealand Cleaners and Caretakers etc. IUOW. On appeal, it was argued that the Registrar was entitled to refuse registration only if all the members of the society could conveniently belong to one existing union. This interpretation of section 168(2) was rejected by the Court, (Northern Totalisator and Allied Employees' Association v. Registrar, 1976) which held that the expression "a then existing union" included the plural and therefore the Association had not satisfied the burden of proof and were not entitled to registration.

A more recent example of a middle management collective seeking registration is that of the Tasman-Kaingaroa Staff Association in 1976. The Registrar refused to register the Association, invoking section $168(2)$, to state that its members could conveniently belong to one of the Auckland Clerical Workers' IUOW, the New Zealand Painters' IUOW or the New Zealand Engineers' etc. IUOW. In relation to the clerical workers in the applicant association, it was argued that although they were covered by the Clerical Workers' Union, they were not covered by the award because of a salary bar, thus making this union one to which they could not conveniently belong. The Court agreed with this argument and stated that these workers did constitute a body of employees which could more conveniently be covered by a new union such as that proposed (The Tasman-Kaingaroa Staff Association Inc. v. Registrar, 1976). Furthermore, these employees were inadequately provided with a means of negotiating with their employers. Nevertheless, 
this finding was one of several, including the critical decision that the membership clause was too broadly drafted and that therefore registration would have to be refused in the interim.

The Registrar's decision was thereby upheld but his decision did not touch on the point that the Court made. In effect, the Registrar's decision amounted to a statement that the matter of convenience outweighed the question of whether or not the existing union would be an effective negotiating body for its new members. One might suggest that this displayed a rather narrow, bureaucratic and impractical approach, insufficient weight being given to the practical implications of the decision.

When the New Zealand University Technicians' Association applied for registration in 1976 , it was also turned down by the Registrar because its members could more conveniently belong to one of the unions opposing the application, notably the New Zealand Printing and Related Trades' IUOW and the New Zealand Engineers' etc. IUOW. The Arbitration Court held that the burden of proving a diversity of interest between the Association's members and those of the opposing unions had been discharged on appeal, and that consequently the Association was entitled to register as a union (New Zealand Association of University Technicians v. Registrar, 1976). Clearly conscious of the practical implications of the issue before it, the Court felt that the critical factors in coming to a decision were as follows:

(1) Only half of the members or less were elegible to join other unions, leaving those ineligible to join without the benefits to which their workmates were entitled.

(2) In relation to the nature of the occupation, members of the Association, as technicians, were employed to assist teaching and research, thereby developing special skills peculiar to this form of employment and taking their careers into widely varying fields. Thus industrial matters affecting the members of the Association were not likely to affect the members of existing unions even though they had the same job description.

As we have seen therefore, in relation to the organisations that have applied for registration as industrial unions, the Registrar and the Arbitration Court have tended to take divergent approaches to the matter. The Registrar has favoured the attitudes adopted by existing unions that regardless of the nature of the occupation, or the effectiveness of the representation that those unions can offer, if, on the face of it, some of the members of the applicant society can belong to existing unions, then the application must be refused.

The Court has gone beyond looking at the job title, to try and establish for what interests protection is being sought (which involves looking at the type of work being done and the interrelationships of the various occupations in question), and how effective this protection will be if the application is refused, (which in turn involves looking at the industrial relations implications for the members of the applicant society if they are taken "under the wing" of one or more existing unions).

The cases outlined relate to a diverse range of white-collar occupations which have been allowed to establish unions to protect their interests. Remarkably, in relation to the occupations of "manager" and "administrator" the Court has taken a different view. Indeed it seems possible to detect in its decisions a strong attitude of opposition to the unionisation of managers and administrators.

The problem here has not centred, as might have been expected, around whether or not a manager is a "worker", but rather, on just what is a "manager"? The case of the application by the New Zealand Association of Professional, Executive, Scientific and Managerial Staffs (APEX) for registration as a union highlights the dilemma faced by many managerial and administrative workers and emphasises the need for a change in the policy direction of the Court to accord these workers the protection given to almost all other groups. 


\section{The APEX case} as follows:

The grounds on which the Registrar refused to register the applicant Association were

(1) That section 163 of the Industrial Relations Act requires workers to be engaged in a specific industry and it was considered the workers in the proposed union did not belong to a specified industry but that their occupations were covered by several industries.

(2) That members of the proposed union could conveniently belong to a number of existing unions; specifically the New Zealand Shop Employees' IUOW, the New Zealand Bank Officers' IUOW and the New Zealand Clerical Workers' Association.

(3) That the membership rule did not comply with section 175 of the Act because it was too broad.

On appeal to the Arbitration Court (New Zealand Association of Professional, Executive, Scientific and Managerial Staffs v. Registrar of Industrial Unions), APEX dealt with each of these objections in turn arguing, in respect of (1) above, that there was no reason why "clerical" workers could constitute a "specific industry" when they were employed horizontally across different industries but "managers" could not be similarly classified. On this point, the Court did not think that the members of APEX constituted a specific industry but did not expand on this statement so that no guidance was given for future applications by this or any other similarly constituted society.

In relation to the Registrar's second ground for refusal, (2) above, APEX argued along broadly similar lines to the case put forward in the appeal by the Tasman-Kaingaroa Staff Association outlined earlier. APEX contended that although, according to the membership rules of the various opposing unions, some of APEX's members were covered by those unions, the same members could not be covered by the opposing unions' awards because of the salary bar, and consequently were effectively banished from the benefits and protection of the industrial conciliation and arbitration system. Evidence was presented in support of APEX's desire to obtain registration in order to provide an effective remedy in the event of a personal grievance, that is, APEX intended to negotiate collective agreements on behalf of its members, a service the opposing unions (with their current coverage clauses) could not offer. The Court did accept that there was a diversity of interest between workers who are in control of other workers, but this concession did not help overcome the major problem with the application which was the breadth of the appellants' membership clause, and its consequent non-compliance with section 175

In relation to the Registrar's third ground for refusal, (3) above, counsel for APEX conceded that it was almost impossible to draft a precise membership clause that would not be in some potential conflict with that of another union and proceeded to argue that in practical terms APEX had been exceedingly conciliatory in its efforts to avoid any objections. Also, that in the light of rapidly changing technology, it was meaningless for membership rules to be the determinant of who has access to the industrial conciliation and arbitration system. The Court was not prepared to accept this view and held that APEX's rule prohibiting membership by any person required by an unqualified preference clause to join an existing union would effectively freeze APEX and other union rules at the time of registration. This did not comply with section 175 and therefore the appeal
was quashed and registration refused.

Perhaps the most curious aspect of the case was the attitude of other trade unions to the application and in particular the Federation of Labour. In its submission to the Court,
the FOL stated:

Federation of Labour policy supports the unionisation of non-unionised workers and to the extent that APEX is trying to organise non-unionised workers we support its registration. 
Unfortunately, APEX's proposed membership rule indicates that it is interested in organising not only workers who are not eligible to join existing unions, but also workers who are at present covered by the membership rule of another union or unions.

This half-hearted statement of support for APEX's cause with its subsequent statement of opposition was followed by the further statement that it was acceptable for existing unions to have vague and imprecise membership clauses because custom and practice would determine who covered whom. However, for a new union, membership rules had to be clear and precise, to avoid the confusion that would be caused for prospective union members, and disputes over coverage that might arise.

Whilst it is certainly true that custom and practice are important in industrial relations, changing circumstances, particularly changes to the employment structure, may quickly render some customs and practices obsolete and inappropriate, especially those in the area of union coverage. One can speculate on whether the FOL's objections to APEX's registration would have been withdrawn had APEX agreed to FOL affiliation. The Early Childhood Workers' IUOW had few problems with its recent registration after it sought the FOL's advice and help. However, this was not what APEX wanted. As APEX's Mr Trott (National Business Review, 1983) told the Court:

... in short, they (managers) wish to organise their own affairs in an autonomous, nonaligned way. Management does not want to be organised from outside either by existing unions or by employers.

... APEX members have a right to conciliation, and arbitration, personal grievance and redundancy provisions provided by industrial law because members are equally threatened in times of high unemployment.

Perhaps APEX's expressed desire to stay outside the mainstream trade union movement was a factor in the FOL's approach to the registration question. But to object to the growth in the unionisation of middle management workers is to ignore the fastest growing area of non-unionised labour in the workforce, a fact that cannot have escaped the attention of the FOL executive. It may also be significant that the FOL is dominated by manual unions ( 4 out of every 5 union members affiliated to the FOL in 1981 were manual workers) many of whom are ambivalent towards the idea of managerial unionism. Whilst aware of their own declining membership base, many are reluctant to embrace the unionisation of the agents of the employers.

One might view the stance of the FOL as conservative and overly protective of existing unions. In a letter to the General Secretary of APEX, the Secretary of the FOL, Ken Douglas, stated that it was not the job of the FOL to solve APEX's coverage problems; that protecting the coverage of their affiliates was more important than assisting APEX to become registered; and that APEX should draw up a membership rule based on its actual membership rather than its desired membership.

The attitude of the various unions opposing APEX's application is understandable to the extent that APEX might have posed a threat to future growth in those unions (notably the various clerical workers' unions, New Zealand Engineers' etc. IUOW and New Zealand Bank Officers' IUOW). However, it is a fact that, without first removing the salary bar in their awards (which many seem reluctant to do), many of these unions are not in a position to offer coverage under existing awards to a great many APEX members and therefore would be gaining these new members, boosting their revenues, but providing little benefit to these workers in return ${ }^{1}$. With the advent of "voluntary unionism" the attitudes of these unions towards new unions such as APEX are likely to harden. A new union represents another avenue of choice to employees and as such, an additional threat to the membership of established unions.

1. It is of course theoretically possible for these unions to negotiate separate awards for APEX members provided that they can persuade the employers and/or the Arbitration Court to agree to such awards. 


\section{Needed changes to trade union registration}

Managers who wish to unionise must attempt to do so in the face of considerable hostility. It is unlikely that their own employers will be sympathetic to the idea, except perhaps in the public sector where traditions are different. Other trade unions also appear antipathetic towards the establishment of new managerial unions, but seem reluctant or unable to service these employees themselves. This is despite the fact that in the light of workforce trends, managerial and administrative workers represent one of the fastest expanding markets for trade union services.

Finally, the law relating to trade union registration operates against the establishment of new unions and in favour of protecting established unions, which are often those with a static or shrinking membership base. Decisions about unionisation are placed in the hands of a government official, and despite the best of intentions, are likely to reflect the interpretation of bureaucratic rules and regulations leading to a different result from that which would eventuate through the óperation of market demand. Such decisions are greatly influenced by the attitudes of established unions to whom the registration of new unions represents competition, and which it is only natural they will oppose.

Perhaps one way forward is to consider the question of "freedom of association". Freedom of association is the direction of change that recent industrial legislation has taken $^{2}$. The term has a variety of meanings within the context of unionism. It can mean "the absolute freedom to join unions, unfettered by laws or regulations" (unrestricted freedom). It can be used in a negative context to mean "freedom not to join a union" (freedom to dissociate). It is this latter meaning which has received so much attention in recent Government legislation. But it can also mean simply the "freedom to choose between unions in the workplace" (pluralism).

New Zealand has a long history of "compulsory unionism", in the sense that workers have been compelled by law to belong to a particular union. This is true of both the "compulsory unionism" set up in 1936 and more recently the unqualified preference provisions which the Arbitration Court could approve if all parties to the award negotiations agreed or if a majority of the adult workers covered by the award so wished. The Industrial Relations Amendment Act 1983 has abolished the legal compulsion to join a union and has replaced it with a "voluntary unionism" that encapsulates the first two of the three meanings of "freedom of association" outlined above, that is, unrestricted freedom and freedom to dissociate. In enacting "voluntary unionism", the legislature has merely said that no preference clauses whether qualified or unqualified can be included in awards or agreed to on an informal basis between unions and employers. This means that in theory no longer is one union exclusively "entitled" to any worker or occupation in relation to membership. However, in practice, this exclusivity of coverage is still maintained because the provisions for the registration of unions in the Industrial Relations Act have been left unchanged by the new legislation.

Currently a "new" union must still be engaged in a specified industry, have a specific membership clause and be the most convenient union (as far as the Registrar is concerned) to which its members may belong. Clearly this situation should be changed. The law now says no union is automatically entitled to the membership of any worker. If that worker feels a union has something to offer him or her, he or she may join it. Consequently, if it has nothing to offer, one is not obliged to join. However, no other union even if it can offer something of value can be registered unless that first union says so.

The implications of this are clear. The registration provisions in the Industrial Relations Act for industrial unions should be abolished to bring the law under one concept of "freedom of association", in all aspects of the term. By legislating for 2 of its 3 meanings, Government has done nothing to attack the monopoly position of established unions and protects them from the impact of market forces.

2. Industrial Relations Amendment Act 1983. 
Workers should be able to decide in a free market, which organisation can best serve their needs. ${ }^{3}$ Provisions restricting entry into that market by other unions should be removed. Registration should become a formality, perhaps with some safeguards regarding the bona fide nature of trade unions before they are registered, and recognition then becomes an issue between the employer and the union. Flexibility and durability should be the critical factors within the trade union movement and not protectionism, that is, which union was registered first. Government, through legislation, should devote its attention to creating a favourable and supportive climate for trade unionism in general, rather than protecting some unions at the expense of others.

The removal of restrictive registration provisions should be accompanied by the abolition of the requirements for a precise membership clause appearing in section 175 of the Industrial Relations Act. Although this would result in trade unions existing side by side with potentially conflicting coverage clauses in their rules, unions would prosper and grow on the basis of which could offer members the most benefits. The result would be a more progressive trade union movement. This does not mean, as some will undoubtedly argue, throwing all trade unions to the wolves. Suitable protection for trade unionism, coupled with appropriate recognition provisions, will ensure that trade unionism will prosper, though some individual unions may not.

There are, then, some steps that central Government can take. Equally, however, there are some initiatives that incorporated societies can take. The advocate for APEX, Mr Rod Trott, stated after the case that there were still some options open to managers to gain access to the provisions of the industrial law (National Business Review, 1983). These include, in the short term, spreading the rules of an existing union to gain coverage for managers and administrators under the umbrella of that union. A longer term option open to APEX-like groups he said, is to set up small, specifically defined industry-based unions.

\section{Summary}

Managers, administrators and some professional workers today may find themselves in a very difficult position regarding their employment security. Economic downturn affects all occupations and all industries, threatening job security right across the spectrum, yet workers in managerial occupations suffer serious disadvantages vis a vis nearly all other workers when it comes to protecting their employment status. Required changes to industrial legislation such as those outlined in this paper are unlikely to occur in the short term, and so managers must determine the steps available to them under present legislation to better secure their position. For those managers wishing to obtain security beyond their individual contract of employment and who decide to form a collective, there appear to be 4 options open to them.

First, they can join an existing union, provided they come within the scope of the union's coverage. Some managers may be reluctant to do this, fearing that by doing so they will become a minority in a large union and be dominated by employees who might have different interests from their own. Such fears are often exaggerated, and many unions, such as the PSA, manage successfully to represent a wide range of staff in the public sector, regardless of occupation.

A second option, should managers be unable to join an existing union due to restrictions on the union's coverage, is to petition the union to widen its coverage to include them. Many unions are able to do this, and some are even willing to negotiate separate awards to cover different interest groups within the same union.

3. It is beyond the scope of this paper to consider the implications of a restructuring of industrial relations in New Zealand in the direction of industry bargaining, and the place that the concept of freedom of association has in such a restructuring. 
A third option open to managers is to form or join an incorporated society. A society for technical and managerial staff already exists (STAMS). This step gives managers and administrators limited access to the protections of the industrial law but does not entitle them to have any dispute compulsorily settled. Furthermore, any agreement negotiated between the society and an employer will not automatically include a personal grievance dispute resolution procedure, unless it is registered under Part X of the Act. The incorporated society does, however, give the collective a legal status, and can serve as a first step along the road to full unionism.

Finally, managers can attempt to register their own union. Managers cannot as yet form their own general industrial unions, commonly found in other countries. Whilst general unions are not feasible at present, industry-based managerial unions have been formed. These have the disadvantage of being small and suffering the shortcomings of smallness: lack of resources, lack of bargaining power, etc. They also perpetuate a state of affairs that both Government and the union movement in general have declared their intentions of remedying - a proliferation of small ineffective unions.

The situation facing many management employees highlights the need for legislative change to allow easier union registration. This would mean that as far as managers were concerned, they would be able to join a union that could offer them award coverage including redundancy and personal grievance provisions. They would no longer be forced to join unions that could not offer, or were not willing to offer them real protections.

The legislative changes outlined here, notably abolishing the registration provisions and the membership clause requirements, would be consistent with the National Government's recent policy of implementing freedom of association. It would leave workers free to choose between unions in the workplace. If legislative changes are not forthcoming, it will be left to "site-specific" groups of managers to take their own initiatives in forming trade union organisations.

\section{References} National Business Review (1983) Bosses can't manage to become unionists-ruling, 14
March, 1983:28.

\section{List of cases}

Shipmasters' Association of New Zealand v. Registrar (1903) B A 259.

Canterbury Chain Store Grocery Managers v. Registrar (1934) B A 607.

Northern Totalisator and Allied Employees' Association v. Registrar [1976] NZLR 23

The Tasman-Kaingaroa Staff Association v. Registrar (1976) I C J 147.

New Zealand Association of University Technicians v. Registrar (1976) I C J 39.

New Zealand Association of Professional, Executive, Scientific and Managerial Staffs v.

Registrar of Industrial Unions Unreported, Arbritration Court 7 March 1983

(A C 19/83) Horn C J 